\title{
URGENSI REGULASI PENYELENGGARAAN PERLINDUNGAN ANAK DI KABUPATEN KEDIRI
}

\section{THE URGENCY OF REGULATIONS FOR THE IMPLEMENTATION OF CHILD PROTECTION IN KEDIRI REGENCY}

\author{
Djoko Siswanto Muhartono \\ Universitas Pawyatan Daha Kediri, Kediri, Indonesia
}

univpawdaha@ymail.com

\begin{abstract}
ABSTRAK
Pada dekade ini perhatian pemerintahan dunia kepada anak-anak semakin besar dan karena disebabkan oleh adanya Deklarasi tentang Hak-hak Anak Internasional pertama kali diadopsi oleh Liga Bangsa-Bangsa sehingga dengan pengakuan atas hak-hak khusus yang dimiliki oleh anak secara historis di mana telah diakui sejak tahun 1924. Pemerintah Indonesia telah meratifikasi Konvensi Hak Anak melalui Keputusan Presiden Nomor 36 Tahun 1990 tentang Pengesahan Convention on The Rights of The Child (Konvensi tentang Hak-hak Anak). Konsekuensi logis dari dorongan dunia internasional di atas, suka dan tidak suka memberi inspirasi kepada pemerintah daerah, khususnya Pemerintah Kabupaten Kediri, Provinsi Jawa Timur, untuk menindaklanjuti dengan menyusun sebuah regulasi atau peraturan daerah tentang Penyelenggaraan Perlindungan Anak. Dalam penelitian ini digunakan metode penelitian yang dipergunakan adalah deskriptif dengan menggunakan instrumen penelitian kuesioner dengan ditambah wawancara untuk mengkonfirmasi semua informasi yang telah dikumpulkan dengan teknik kuesioner 38 (tiga puluh delapan) Organisassi Perangkat Daerah (OPD). Temuan yang dapat diidentifikasi dalam penelitian ini untuk dijadikan materi muatan regulasi peraturan daerahKabupaten Kediri adalah: (1) bagaimanakahhak-hak anak diakui oleh pemerintah dan lembaga sosial; (2)kewajiban orang tua dan keluarga, kewajiban pemerintah daerah ( 3) tanggung jawab pemerintah daerah, masyarakat, orang tua dan/atau keluarga, dunia usaha dan lembaga (4) perlindungan khusus anak; (5) penanganan korban (6) pengasuhan dan pengangkatan anak; (7) larangan; ( 8) kabupaten layak anak; (9) forum anak; (10 )sistem data dan informasi anak; (11) pembinaan, pengawasan, pelaporan; (12) peran serta; (13 ) koordinasi; (14 ) pembiayaan.
\end{abstract}




\title{
Djoko Siswanto Muhartono \\ Urgensi Regulasi Penyelenggaraan Perlindungan Anak di Kabupaten Kediri
}

Kata Kunci:hak anak, kewajiban perlindungan anak, regulasi

\begin{abstract}
In this decade the attention of world governments to children has increased and because of the existence of the Declaration on the Rights of the International Child, which was first adopted by the League of Nations, with the recognition of the special rights that children have historically been recognized since 1924. The Indonesian government has ratified the Convention on the Rights of the Child through Presidential Decree No. 36/1990 on Ratification of the Convention on the Rights of the Child.

The logical consequence of the international encouragement above, likes and dislikes, inspires local governments, especially the Kediri Regency Government, East Java Province, to follow up by drafting a regulation or regional regulation on the Implementation of Child Protection. In this study, the research method used is descriptive using a questionnaire research instrument plus interviews to confirm all information that has been collected using a questionnaire technique 38 (thirty eight) Regional Apparatus Organizations (OPD).

The findings that can be identified in this study to be used as material for the content of local regulations in Kediri Regency are: (1) how are children's rights recognized by the government and social institutions; (2) obligations of parents and families, obligations of local governments (3) responsibilities of local governments, communities, parents and/or families, businesses and institutions (4) special protection of children; (5) victim handling (6) child care and adoption; (7) prohibition; ( 8) child-friendly districts; (9) children's forums; (10 ) child data and information system; (11) guidance, supervision, reporting; (12) participation; (13 ) coordination; (14 ) financing.
\end{abstract} Keywords: children's rights, child protection obligations, regulation

\section{PENDAHULUAN}

Dengan adanya Deklarasi tentang Hak-Hak Anak Internasional pertama kali diadopsi oleh Liga Bangsa-Bangsa (Jones; 2009) telah terjadi pengakuan atas hak-hak khusus yang dimiliki oleh anak secara historis di mana telah diakui sejak tahun 1924. Konsensus internasional yang dikembangkan untuk menegaskan kebutuhan adanya instrumen baru yang lebih tegas menjamin hak-hak khusus dan istimewa anak menjadikan pada tahun 1989 Konvensi Perserikatan Bangsa- 
Bangsa tentang hak-hak anak diadopsi oleh Sidang Majelis Umum. Konvensi tersebut kemudian dengan cepat menjadi perjanjian hak-hak azasi manusia yang paling luas diratifikasi dalam sejarah. Pemerintah Indonesia telah meratifikasi Konvensi Hak Anak melalui Keputusan Presiden Nomor 36 Tahun 1990 tentang Pengesahan Convention on The Rights of The Child (Konvensi tentang Hakhak Anak).

Adapun instrumen yang mengakui dan menjamin hak-hak anak di level internasional, diantaranya adalah:

(a) Piagam Afrika tentangHak-hak dan Kesejahteraan Anak, OrganisasiPersatuan Afrika yang sekarangdisebut Uni Afrika (The African Charter on the Rights and Welfare of the Child of the Organisation for African Unity) tahun 1993;

(b) Konvensi-konvensi Jenewa mengenai Hukum Humaniter Internasional (1949) dan Protokol Tambahannya (1977);

(c) Protokol bagi Konvensi Perserikatan Bangsa-bangsa tentang Kejahatan Transnasional Terorganisasi untuk Mencegah, Menekan dan Menghukum Perdagangan Manusia, khususnya Wanita dan Anak; dan

(d) Konvensi Buruh Internasional No.138 (1973), yang menyatakan bahwa, secara umum, seseorang yang berusia di bawah 18 tahun, tidak boleh dipekerjakan dalam bidang-bidang pekerjaan yang berbahaya bagi kesehatan dan perkembangan mereka, dan Konvensi Organisasi Buruh Internasional No. 182 (1999) mengenai Pelarangan dan Tindakan Segera untuk Menghapus Bentuk-bentuk Pekerjaan Terburuk bagi Anak.

Negara Indonesia juga menunjukkan penghargaan dan pengakuan akan hak-hak anak melalui Undang-Undang Nomor 23 Tahun 2002 yang telah diubah dengan adanya Undang-Undang Nomor 35 Tahun 2014tentang Perlindungan Anak, dimana isi Undang-Undang tersebut adalah mengakui keberadaan hak-hak anak. Undang-Undang tersebut secara mendasar menyebutkan anak secara asasi memiliki sejumlah hak yang melekat yang meliputi hak-hak dasar, yaitu Hak Hidup, Hak Tumbuh Kembang, Hak Memperoleh Pendidikan dan Pengajaran, Hak Perlindungan dan Hak Partisipasi.Indonesia sebagai salah satu negara yang ada di dunia telahmemuatpengakuan dan perlindungan hak asasi warga negara dalam berbagai peraturan perundang-undangan seperti dalam Pembukaan UUD 1945, Batang Tubuh UUD 1945, UU Nomor 39 Tahun 1999 tentang Hak Asasi Manusia, dan UU Nomor 26 Tahun 2000 tentang Pengadilan Hak Asasi Manusia. Indonesia sudah selayaknya melindungi segenap hak yang dimiliki oleh tiap-tiap warga Negara sesuai dengan tugasnya sebagai suatu negara dari setiap pelanggaran akan hak asasi manusia yang mengancam warganya. 


\section{Djoko Siswanto Muhartono}

Urgensi Regulasi Penyelenggaraan Perlindungan Anak di Kabupaten Kediri

Anak merupakan bagian dari asset bangsa yang tidak ternilai harganya, sebab mereka adalah generasi pelanjut perjuangan bangsa yang akan menerima tongkat kepemimpinan di masa yang akan datang. Agar anak mampu melaksanakan tugas-tugas melanjutkan estafet kepemimpinan dan pembangunan dari generasi pendahulunya, maka mereka perlu mendapatkan kesempatan yang seluas-luasnya untuk tumbuh dan berkembang secara wajar baik rohaniah, jasmaniah maupun sosial. Memperhatikan hal tersebut, maka negara harus menjamin dan memenuhi hak-hak anak, yang merupakan juga prinsip dalam pelaksanaan Perlindungan anak, dimana meliputi:

(1) Hak Untuk Hidup, diantaranya hak untuk mencapai tingkat kesehatan tinggi dan mendapatkan perawatan terbaik. Anak memerlukan makanan dalam jumlah yang cukup, sehat dan bergizi, serta akses kesehatan yang optimal. Selain itu terdapat hak mendapatkan pelayanan kesehatan, air bersih, tempat berteduh dan aman, serta berhak untuk memiliki nama dan kebangsaan;

(2) Hak Untuk Berkembang, meliputi segala bentuk pendidikan (formal dan non formal) dan hak untuk mencapai standard hidup yang layak bagi perkembangan fisik, mental, spiritual, moral dan sosial. Anak berhak mendapatkan pendidikan, istirahat dan rekreasi, serta ikut serta dalam semua kegiatan kebudayaan; Selain itu untuk memenuhi Hak Tumbuh Kembang, anak juga memerlukan ruang untuk bermain, berolahraga, pendidikan yang sesuai dengan perkembangan fisik dan jiwanya;

(3) Hak Memperoleh Pendidikan dan Pengajaran

Setiap Anak berhak memperoleh pendidikan dan pengajarandalam rangka pengembangan pribadinya dan tingkat

kecerdasannya sesuai dengan minat dan bakat.Setiap Anak berhak mendapatkan perlindungan di satuanpendidikan dari kejahatan seksual dan Kekerasan yang dilakukanoleh pendidik, tenaga kependidikan, sesama peserta didik,dan/atau pihak lain.Selain mendapatkan Hak Anak, Anak Penyandang Disabilitas berhakmemperoleh pendidikan luar biasa dan Anak yang memilikikeunggulan berhak mendapatkan pendidikan khusus.

(4) Hak Atas Perlindungan; meliputi perlindungan dan terbebas dari diskriminasi, tindak kekerasan dan ketelantaran terhadap anak. Dalam hal ini anak berhak dilindungi dari eksploitasi ekonomi dan seks, diskriminasi, kekerasan, bahkan penelantaran (termasuk cacat fisik maupun mental, pengungsi, dan anak yatim piatu); setiap penyelenggara pemerintahan, masyarakat dan orangtua dituntut untuk memahami dan peduli terhadap hak-hak anak. Adanya perangkat hukum dan aparat hukum yang membela kepentingan anak diperlukan untuk upaya perlindungan ini. Peraturan perundangan yang berprinsip membela kepentingan terbaik bagi 
anak (the best interest of the child) diperlukan untuk mewujudkan perlindungan yang bersifat legal;

(5) Hak Untuk Berpartisipasi, meliputi hak anak untuk menyatakan pendapat dalam segala hal mempengaruhi anak. Hak untuk berpartisipasi dalam keluarga, dalam kehidupan sosial, bebas mengutarakan pendapat, hak untuk mendapatkan informasi, serta hak untuk didengar pandangan dan pendapatnya. Anak berhak memerlukan akses, media dan sarana yang menunjang hak partisipasi. Anak juga berhak untuk mendapatkan informasi yang benar dan suara mereka perlu didengar dan mendapatkan perhatian.

Pemenuhan terhadap lima hak dasar tersebut merupakan kewajiban dan tanggung jawab negara, pemerintah baik di tingkat pusat maupun daerah, serta didukung oleh masyarakat dan keluarga. Dalam konteks pemerintahan, pemenuhan hak dasar anak dan penyelenggaraan perlindungan terhadap anak merupakan tanggungjawab pemerintah Kabupaten Kediri bersama dengan masyarakat.Oleh karena itu peraturan daerah yang mengatur tentang PenyelenggaraanPerlindungan Anak (PPA) sangatlah dibutuhkan.

Penyelenggaraan Perlindungan Anak adalah kabupaten yang mempunyai system pembangunan berbasis hak anak dengan mengintegrasikan komitmen dan sumberdaya pemerintah, masyarakat dan dunia usaha, yang terencana secara menyeluruh dan berkelanjutan dalam kebijakan, program dan kegiatan untuk menjamin terpenuhinya hak dan perlindungan anak, yaitu:

- Secara Umum: Untuk memenuhi hak dan melindungi anak

- Secara Khusus: Untuk membangun inisiatif pemerintah kabupaten yang mengarah pada upaya transformasi Konvensi Hak Anak (Convention on the Rights of the Child) dari kerangka hokum ke dalam definisi, strategi dan intervensi pembangunan, dalam bentuk: kebijakan, program dan kegiatan pembangunan yang ditujukan untuk pemenuhan hak dan perlindungan anak (PHPA) pada suatu wilayah kabupaten.

Sedangkan peraturan yang melandasi PPA, baik secara internasional dan nasional adalah:

1. Internasional, yang terdiri dari:
a. Deklarasi Hak Asasi Manusia
b. Konvensi Hak Anak
c. World Fit For Children

2. Nasional, yang terdiri dari:
a. Undang-Undang Dasar 1945 Pasal 28b ayat 2 dan 28c
b. Undang-Undang No. 17 Tahun 2007 tentang RPJPN 2005-2025
c. Undang-Undang No. 23 Tahun 2002 tentang Perlindungan Anak 


\section{Djoko Siswanto Muhartono}

Urgensi Regulasi Penyelenggaraan Perlindungan Anak di Kabupaten Kediri

d. Undang-Undang No. 23 Tahun 2014 tentang Pemerintahan Daerah

e. Undang-Undang No. 35 Tahun 2014 perubahan atas 23/2002 tentang Perlindungan Anak

f. Undang-Undang No. 12 Tahun 2011 tentang Sistem Peradilan Pidana Anak

g. Peraturan Presiden No. 18 Tahun 2020 tentang RPJMN 2020-2024

h. Keputusan Presiden No. 36 Tahun 1990 tentang Pengesahan Convention on the Rights of the Child (Konvensi tentang Hak-Hak Anak)

i. Inpres No. 01 Tahun 2010 tentang Program Prioritas Pembangunan Nasional

j. Inpres No. 05 Tahun 2014 tentang Gerakan Nasional Anti Kejahatan Seksual terhadap Anak (GN-AKSA)

Dengan demikian negara, pemerintah, pemerintah daerah, masyarakat, keluarga dan orang tua atau wali berkewajiban dan bertanggungjawab terhadap penyelenggaraan perlindungan anak. Hubungan atau keterkaitan antara deklarasi Hak Asasi Manusia, Konvensi Hak Anak dan Penyelenggaraan Perlindungan Anak, yang mendasari terwujudnya dan terlaksananya Perlindungan anak dapat digambarkan sebagaiberikut:

\section{Gambar 1}

\section{Hubungan Antara HAM, KHA dan PPA}

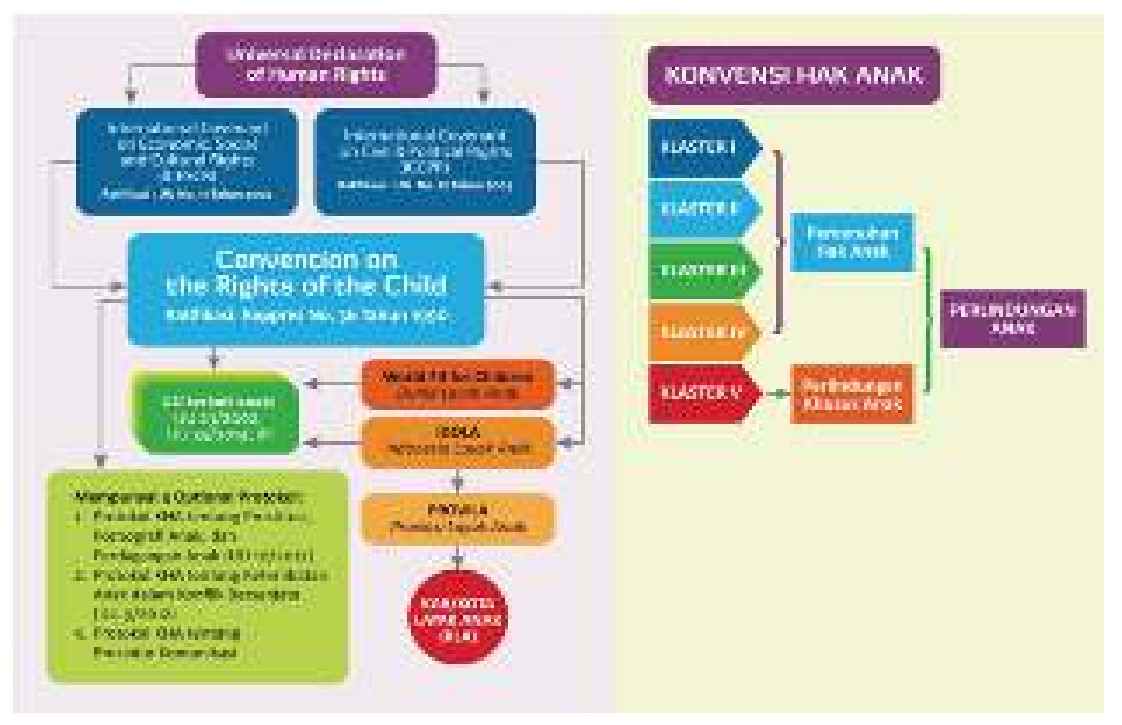

Sumber: KPPPA RI, 
Selain itu dalam rangka memenuhi kewajiban dalam pemenuhan hak anak, maka Hak Anak yang dimaksud dalam kerangka Konvensi Hak Anak yang merupakan kebijakan PPA dikelompokkan kedalam lima Klaster, yaitu: (1) Hak Sipil dan Kebebasan; (2) Lingkungan Keluarga dan Pengasuhan Alternatif; (3) Kesehatan Dasar dan Kesejahteraan; (4) Pendidikan, Pemanfaatan Waktu Luang dan Kegiatan Budaya; dan (5) Perlindungan Khusus. Berkaitan dengan hal ini maka kabupaten dituntut untuk melakukan pencegahan dan penanganan guna merumuskan serta menyelenggarakan regulasi dengan memiliki dan memperkuat perangkat peraturan daerah yang mampu memberikan kepastian hukum dan kejelasan tanggungjawab berbagai pihak yang berkompeten dalam memberikan pelayanan bagi setiap anak dengan memfokuskan pada kebutuhan akan kesejahteraan dan perlindungan bagi setiap anak, sehingga terwujud perlindungan anak.

\section{Gambar 2}

\section{Klaster Konvensi Hak Anak}

\section{KLASTER KONVENSI HAK ANAK}

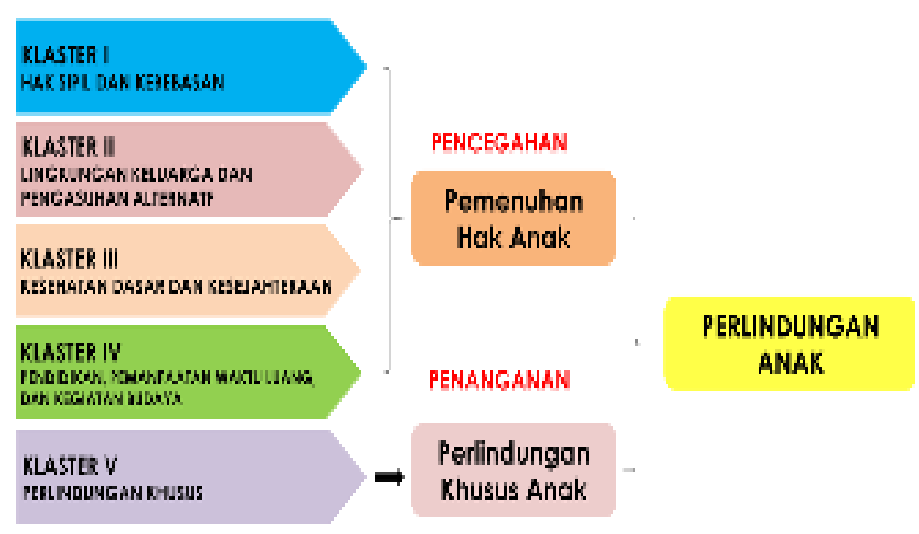

Sumber: KPPPA 2020.

Menurut UNICEF (2014), dalam konsep PPA, terdapat beberapa elemen yang perlu dipertimbangkan, yaitu:(a) participation in decision making; (b) child friendly legal framework; (c) city wide child right strategies; (d) child right unit or coordinating mechanism (services); (e) child impact assessment; (f) children's budget; (g) city child reports; (h) advocating child rights (child protection); and (i) independent advocacy for children. Semua aspek ini sudah barang tentu harus dipertimbangkan dalam proses penyusunan naskah akademik dan peraturan daerah (Perda) yang akan disusun.

Berbagai permasalahan anak di Kabupaten Kediri yang menjadi tanggung jawab pemerintah antara lain: penerbitan akta kelahiran, kesehatan anak, pendidikan anak, anak yang berhadapan 


\section{Djoko Siswanto Muhartono}

Urgensi Regulasi Penyelenggaraan Perlindungan Anak di Kabupaten Kediri

dengan hukum, sarana bermain, pelayanan bagi anak diffabel, partisipasi anak dan jejaring komunikasi dan anak jalanan/anak terlantar.

Pencatatan kelahiran anak merupakan hal yang penting untuk dilakukan. Hal ini untuk memberikan identitas diri terhadap anak, yang kemudian dituangkan dalam akta kelahiran. Pada bidang administrasi kependudukan, masih terdapat anak-anak di Kabupaten Kediri yang belum terpenuhi hak hukumnya. Berdasarkan data yang ada, pada tahun 2018 jumlah anak-anak di Kabupaten Kediri usia 0-14 tahun yang sudah memiliki akta kelahiran sebanyak 285.274 anak dan yang belum memiliki hak pengakuan negara tentang status individu, perdata dan kewarganegaraannya sebanyak 54.448 anak.

Berkurangnya peluang anak untuk melanjutkan kejenjang pendidikan yang lebih tinggi dipengaruhi oleh banyak faktor, diantaranya adalah kemiskinan. Padahal sebagaimana disebutkan dalam Undang-Undang Perlindungan anak bahwa setiap anak berhak memperoleh pendidikan.

Bidang kesehatan setiap anak memiliki hak untuk memperoleh akses kesehatan yang optimal. Jumlah kecukupan gizi anak tahun 2018 sebanyak 90.290 dan tahun 2019 sebanyak 85.221, karena itu revitalisasi puskesmas menjadi penting dan mendesak. Jumlah puskesmas sebanyak 37 dan puskesmas pembantu 80 dengan jumlah kunjungan bayi dan anak sebanyak masing-masing 24.385 bayi dan 97.712 anak. Mengingat kasus kesehatan anak sering memprihatinkan, terutama bagi anak-anak dari keluarga yang kurang mampu. Beberapa kasus seperti anak yang mengalami kekurangan gizi (malnourish), gizi buruk, diare dan malaria yang menimpa anak-anak masih ditemui di Kabupaten Kediri. Sehingga keberadaanposyandu harus lebih diaktifkan dan diberdayakan untuk mengurangi resiko pada anak serta peran Posyandu sebagai institusi terdekat di komunitas menjadi lebih bermakna dalam meningkatkan derajat kesehatan anak.

Lahan tempat bermain diperlukan setiap anak sebagai sarana tumbuh kembang yang sehat. Dunia anak memang dunia bermain dan bermain menjadi hak dan kebutuhan penting bagi anak. Tempat bermain bagi anak untuk berlatih peran, ekspresi diri, eksperimentasi sosial dan pengembangan fisik dan psikis. Untuk itu pada setiap komunitas agar disediakan tempat bermain bagi anak. Tempat bermain tersebut haruslah sehat, aman dan nyaman serta bersifat edukatif rekreatif. Tempat bermain tersebut harus disediakan pemerintah dan dapat dinikmati oleh seluruh anak yang ada dalam komunitas tersebut secara gratis.

Kabupaten Kediri, seperti kabupaten besar lainnya di Indonesia, ditemukannya kasus anak yang mengalami masalah kekerasan fisik, psikis, seksual dan sosial. Seperti kasus-kasus anak korban penganiayaan, penelantaran, pengusiran dan perlakuan salah (abuse) oleh orangtua atau pun 
orang lain. Bagi anak yang mengalami masalah tersebut pemerintah seharusnya menyediakan children crisis center (CCC) untuk mendampingi yang terdiri dari berbagai unsur yang meliputi: konselor, pendidik, dokter, psikolog, rohaniwan dan berjaringan dengan pengacara anak serta Unit PPA di Kepolisian. CCC hendaknya bersifat sebagai rumah aman (shelter) bagi anak dan tempat yang memberikan kenyamanan dan setiap anak yang mengalami kejadian dan traumatis mendapatkan akses yang tidak terbatas untuk menggunakan fasilitas tersebut.

Bagi para anak berkebutuhan khusus baik fisik ataupun non-fisik, permerintah memiliki kewajiban untuk memenuhi hak-hak mereka agar mereka mampu untuk tumbuh kembang seperti layaknya anak normal lainnya. Anak cacat tidak butuh dikasihani, tetapi mereka memerlukan adanya pengakuan dan perlindungan hak sebagai sesama anak bangsa, sayangnya masih banyak sarana yang belum dinikmati anak-anak penyandang cacat sebagai sesama warga bangsa dan warga negara, sarana pendidikan yang mendukung anak berkebutuhan khusus juga belum diperhatikan secara optimal. Bidang pendidikan juga terkait dengan kesehatan diantaranya seberapa banyak sekolah sehat dan program-program terkait kesehatan siswa dan sanitasi sekolah tersedia dengan layak, kurangnya pojok-pojok literasi untuk mengasah kreatifitas siswa juga terlihat meninjol.

Anak terlantar yang berkeliaran di jalanan atau sering disebut anak jalanan (anjal) merupakan permasalahan di kota besar di Indonesia yang agak sulit diselesaikan. Ada beberapa jenis anak jalanan. Ada yang sesekali waktu turun ke jalan karena waktu luang dan diajak temanteman untuk mencari uang sekedarnya. Mereka masih dalam tanggungan orangtua namun cukup disayangkan karena masih banyak orang tua justru memanfaatkan anak untuk mencari uang diantaranya dijalanan dan disektor informal . Kalau memperoleh uang digunakan untuk bersenangsenang, kadang melanggar norma, seperti untuk mabuk, berjudi dan ke tempat pelacuran. Ada yang sudah putus sekolah dan harus membantu orangtua dengan cara mengamen atau mengemis di jalanan. Ada juga yang lepas dari orangtua dan menggelandang di berbagai tempat tidak menentu.

Anak-anak yang terlantar dan berkeliaran di jalanan harus memperoleh perlindungan hak mereka. Mereka harus diperhatikan hak pendidikan, kesehatan, latihan keterampilan, bimbingan sosial, mental dan spiritual demi menyongsong hari depan mereka. Pengaruh negatif di jalan dari tindakan kriminal perlu dihentikan. Untuk itu pemerintah telah bekerjasama dengan berbagai pihak dalam membina kegiatan di rumah singgah, namun usaha tersebut banyak yang mengatakan masih belum sepenuhnya berhasil. Untuk melakukan gerakan sayang anak jalanan tidak cukup dengan menghimbau masyarakat untuk tidak memberi sedekah kepada anjal yang mengamen atau mengemis di jalanan. Perlu gerakan masyarakat peduli mengenai kesulitan membina anak jalanan dari upaya menghilangkan stigma yang disandang, baik sebagai pelaku atau penyandang pembuat 


\section{Djoko Siswanto Muhartono}

Urgensi Regulasi Penyelenggaraan Perlindungan Anak di Kabupaten Kediri

resah masyarakat. Kehidupan jalanan tidak ada harapan masa depan. Pemerintah akan memberikan perlindungan hak kepada anak-anak terlantar ini dan memberikan sanksi tegas kepada pihak-pihak yang melakukan eksploitasi.

Permasalahan sosial anak di Kabupaten Kediri hingga kini tidak jauh berbeda dengan tahun sebelumnya, kasus tindak kekerasan dan pelanggaran terhadap hak anak masih ada beberapa kasus. Selain data dan laporan kasus tentang child abuse tidak lengkap seringkali kasus-kasus demikian terbungkus oleh kebiasaan masyarakat yang meletakkan persoalan anak menjadi masalah internal keluarga. Tindak kekerasan dan child abuse di semua lapisan masyarakat tersembunyi di balik nilainilai tertentu dalam masyarakat, misalnya nilai budaya, atau tradisi dalam mendidik anak. Kondisi ini menimbulkan pada minimnya pencatatan atas pelaporan dan penyelesaian secara hukum pada pelaku kekerasan pada anak. Hal ini disebabkan oleh cara penyelesaian yang dilakukan secara kekeluargaan dan tanpa melibatkan institusi hukum.

Sementara sistem nilai universal dalam hukum adalah keadilan, kebenaran, kepastian hukum, kesetaraan dan menjunjung tinggi Hak Asasi Manusia (HAM). Hak-hak anak di Indonesia sudah diatur dengan adanya Konversi Hak Anak (KHA) pada tahun 1989 yang diratifikasi pemerintah RI melalui Kepres Nomor 36 tahun 1990. Kemudian ditindak lanjuti dengan disahkannya Undang-Undang No. 23 tahun 2002 tentang Perlindungan Anak. Namun demikian pada tingkat implementasi di daerah masih diperlukan adanya aturan yang lebih spesifik mengingat pada tiap daerah permasalahan yang berkaitan dengan anak berbeda pula dengan melihat situasi dan kondisi di Kabupaten Kediri.

Berdasakan uraian di atas ada beberapa permasalahan yang dapat diidentifikasi sebagai berikut: (1) kurang optimalnya pelayanan pemerintah daerah terhadap perlindungan anak dalam memperoleh pelayanan hak-hak dasar anak sebagai warga negara dalam berbagai bidang kehidupan; (2) masih sedikit ketersediaan infrastruktur anak dan anak disabilitas yang mendukung terpenuhinya hak dasar mereka, sehingga terkesan masih ada "diskriminasi" sosial yang menempatkan mereka rentan untuk diperlakukan tidak adil dan tidak manusiawi dari masyarakat dan pemerintah daerah; (3) belumoptimalnya perlindungan khusus untuk anak berkebutuhan khusus, berhadapan masalah hukum, korban kekerasan dan korban bencana; dan (4) belum adanya regulasi yang menjadi paying hukum bagi Pemerintah Daerah Kabupaten Kediri untuk memberikan fasilitasi yang menjamin terpenuhinya hak-hak dasar mereka sebagai manusia yang memiliki hak asasi manusia yang sama. Keberadaan peraturan daerah ini akan berpengaruh terhadap koordinasi 
dan fasilitasi program menjadi sinergis dan terintegrasi antar sektor dalam organisasi perangkat daerah maupun masyarakat.

Adapun tujuan yang hendak dicapai dari regulasi tentang penyelenggaraan perlindungan anak adalah melakukan penelitian atau pengkajian terkait dengan kewajiban Pemerintah Daerah dalam melakukan program perlindungan anak. Oleh karena itu, tujuan pokok dari penyusunan regulasi akademik peraturan daerah ini adalah sebagai berikut: (1) terselenggaranya peningkatan akses dan mutu pelayanan pemenuhan hak-hak dasar anak sehingga tumbuh kembang berjalan normal pada umumnya; (2) tersedianya infrastruktur yang memadahi bagi anak dan anak disabilitas dalam memperoleh hak-hak dasar mereka dalam segala bidang kehidupan mereka; (3) adanya perlindungan khusus bagi anak, baik berupa kebijakan maupun lembaga dengan program yang memadai terkait permasalahan tersebut; dan (4)mewujudkan peraturan dan kepastian hukum yang peduli pada anak dalam rangka pemenuhan kategori perlindungan anak sesuai prinsip yang menjunjung nilai-nilai penghargaan terhadap HAM, serta terbentuknya sinergi dan kerjasama antar seluruh pemangku kepentingan, organisasi profesi, akademisi, swasta dan partisipasi masyarakat dalam memberikan layanan untuk menjamin terpenuhinya hak anak.

\section{METODOLOGI}

\section{a. Jenis Penelitian}

Jenis penelitian untuk menggambarkan urgensinya regulasi tentang penyelenggaraan perlindungan anak, dipilih jenis penelitian deskripsi, yang menurut definisi bahwa peneliyian deskriptif merupakan penelitian yang dilakukan oleh peneliti untuk mengetahui nilai variabel mandiri, baik satu variabel atau lebih tanpa membuat perbandingan, atau menghubungkan antara variabel satu dengan variabel lain.”(Sugiyono, 2003:11)

\section{b. Teknik Pengumpulan Data}

Teknik pengumpulan data dilakukan dengan teknik sebagai berikut:

\section{1) Wawancara}

Peneliti memberikan beberapa pertanyaan kepada subyek penelitian baik terstruktur maupun bebas adalam upaya untuk memperoleh data secara lebih mendalam tentang penyelenggaraan perlindungan anak yang dilakukaan oleh Organisasi Pemerintah Daerah (OPD) yang terkait dengan sasaran penelitian. Sedangkan secara umum wawancara dilakukan dengan menanyakan tentang kegiatan yang dilakukan oleh Organisasi Perangkat Daerah (OPD) di Pemerintah Kabupaten Kediri, Provinsi Jawa Timur. 


\section{Djoko Siswanto Muhartono}

Urgensi Regulasi Penyelenggaraan Perlindungan Anak di Kabupaten Kediri

\section{2) Dokumentasi}

Proses dokumentasi dilakukan dengan mengumpulan data dari OPD Pengumpulan data dilakukan dengan menghimpun dokumen-dokumen yang ada di 38 OPD Pemerintah Kabupaten Kediri.

\section{c. Metode}

Untuk mencapai tujuan penyusunan Naskah Akademik ini dilakukan dengan menggunakan 2 jenis metode. Pertama, menggunakan analisis data sekunder yaitu melakukan analisis isi pada peraturan perundang-undangan yang sudah ada untuk mengetahui kedudukan Rancangan Peraturan Daerah tentang Penyelenggaraan Perlindungan Anak di Kabupaten Kediri saling mendukung dan tidak bertolak belakang satu sama lain. Peraturan perundangan yang akan dianalisis yaitu:

1) Undang-Undang Dasar 1945 Pasal 28b ayat 2 dan 28c

2) Undang-Undang No. 17 Tahun 2007 tentang RPJPN 2005-2025

3) Undang-Undang No. 23 Tahun 2002 yang diubah menjadi Undang-Undang No. 35 Tahun 2014 tentang Perlindungan Anak

4) Undang-Undang No. 23 Tahun 2014 tentang Pemerintahan Daerah

5) Undang-Undang No. 35 Tahun 2014 perubahan atas 23/2002 tentang Perlindungan Anak

6) Undang-Undang No. 12 Tahun 2011 tentang Sistem Peradilan Pidana Anak

7) Peraturan Presiden No. 18 Tahun 2020 tentang RPJMN 2020-2024

8) Keputusan Presiden No. 36 Tahun 1990 tentang Pengesahan Convention on the Rights of the Child (Konvensi tentang Hak-Hak Anak)

9) Inpres No. 01 Tahun 2010 tentang Program Prioritas Pembangunan Nasional

10) Inpres No. 05 Tahun 2014 tentang Gerakan Nasional Anti Kejahatan Seksual terhadap Anak (GN-AKSA)

Kedua, dengan menggunakan metode analisis data primer yang dikumpulkan dengan cara melakukan wawancara mendalam (depth interview) dan Focus Group Discussion (FGD) dengan OPD terkait, agar permasalahan yang akan diatur dalam Rancangan Peraturan Daerah (Ranperda) akan tercakup dan diatur secara jelas dan sistematis. Selanjutnya, semua pemangku kepentingan (stakeholders)dapat melakukan upaya mewujudkan penyelenggaraan perlindungan anak dalam pembangunan berdasar pada tupoksi, kompetensi dan kapasitas masing-masing sesuai dengan kewenangan yang diatur dalam Rancangan Perda. 


\section{HASIL DAN PEMBAHASAN}

Berdasarkan koleksi data yang ada telah menghasilkan informasi tentang penyelenggaraan perlindungan anak setiap OPD yang terkait di Pemerintah Kabupaten Kediridan kemudian dilakukan pembahasan.

Mengacu pada definisi anak sebagai seseorang yang belum berusia 18 (delapan belas) tahun, termasuk anak yang masih dalam kandungan, jumlah penduduk Kabupaten Kediri tahun 2019 sebesar 1.662.508 jiwa, sebanyak 384.703 jiwa termasuk dalam kategori usia 0 tahun - 17 tahun. Apabila dilihat lebih lanjut, jumlah anak laki-laki sejumlah 198.026 jiwa lebih banyak disbanding anak perempuan sejumlah 186.677 jiwa.

Dilihat dari rentang usia, paling banyak berada diusia 9-10 tahun baik untuk laki-laki dan perempuan. Laki-laki sebanyak 13.419 jiwa dan perempuan sebanyak 12.670 jiwa. Kondisi tersebut tentu menuntut pemerintah untuk memberikan perhatian lebih kepada anak-anak yang berada dalam rentang usia tersebut, mengingat jumlah mereka yang lebih banyak dari rentang usia lainnya. Adapun anak-anak yang berusia Balita (bawah lima tahun) sebanyak 49.292 untuk laki-laki dan 46.369 untuk perempuan.

Oleh karena itu, anak-anak tersebut di atas dan sejalan dengan pendapat O'Donnel dan Seymour (2004; 2006) menganjurkan 10 (sepuluh) cara yang dapat ditempuh untuk menciptakan lingkungan yang melindungi bagi anak, perlu segera dilaksanakan anjuran tersebut.

a. Mengatasi dan melakukan persiapan menghadapi dampak dari kemiskinan ekonomi dan sosial;

b. Advokasi pada tingkat nasional dan memulai dialog pada berbagai tingkatan, mulai dari tingkat pemerintah sampai pada tingkat komunitas, keluarga dan anak-anak;

c. Advokasi internasional, termasuk didalamnya melalui mekanisme hak-hak asasi manusia internasional. Langkah ini juga dapat berbentuk upaya mendorong adanya agenda perlindungan anak pada pertemuan tingkat regional;

d. Mendorong perubahan perilaku masyarakat, terus-menerus melawan sikap dan tradisi yang menguatkan pelanggaran pada upaya perlindungan anak dan mendukung sikap dan tradisi yang menguatkan upaya perlindungan anak. Langkah inidapat berbentuk kampanye nasional atau edukasi melalui media;

e. Melakukan penguatan kemampuan untuk menilai dan menganalisis masalah perlindungan anak. Ketiadaan kemampuan tersebut menjadikan pemerintah dan masyarakat tidak mampu secara efektif melakukan respon atas tindak pelanggaran hak anak;

f. Menciptakan dan mengusahakan diterapkannya mekanisme perlindungan anak dan menyediakan sumberdaya yang dibutuhkan bagi mereka yang melakukan perawatan dan pelayanan 


\section{Djoko Siswanto Muhartono}

Urgensi Regulasi Penyelenggaraan Perlindungan Anak di Kabupaten Kediri

perlindungan anak sehingga mereka memiliki pengetahuan dan ketrampilan untuk mengupayakan perlindungan anak. Langkah ini dapat dilakukan melalui pendidikan dan pelatihan;

g. Mendorong terus menerus kesadaran bahwa standar hukum adalah hal yang sangat penting dalam upaya melindungi anak, dan standar hukum tersebut harus diketahui, dipahami, diterima dan ditegakkan. Langkah-langkah ini termasuk juga memeriksa, memperbaiki perundangan yang sudah ada bahkan jika diperlukan menyusun perundangan baru. Pengawasan pada penegakan hukum juga menjadi langkah penting untuk memastikan bahwa perundangan yang ada telah ditaati dan dijalankan dengan benar;

h. Membangun dan memeriksa kembali sistem monitoring nasional untuk memastikan bahwa sistem yang ada benar-benar telah mencakup masalah perlindungan anak. Salah satu cara penting yang dapat dilakukan dalam hal ini adalah melakukan pencatatan sehingga statistic berbagai aspek perlindungan anak menjadi jelas dan dapat diamati perkembangannya;

i. Memastikan terbukanya akses bagi pemulihan dan pengintegrasian kembali anak-anak yang menjadi korban pelanggaran;

j. Memajukan partisipasi anak dan menguatkan resiliensi anak.

Dalam melaksanakan perlindungan terhadap anak, Kabupaten Kediri telah mempunyai Peraturan Daerah Kabupaten Kediri Nomor 6 Tahun 2010 tentang Perlindungan Perempuan dan Anak Korban Kekerasan dan Peraturan Bupati Kediri Nomor 8 Tahun 2015 tentang Petunjuk Pelaksanaan Peraturan Daerah Kabupaten Kediri Nomor 6 Tahun 2012 Tentang Perlindungan Terhadap Perempuan dan Anak Korban Kekerasan.

Peraturan Daerah tersebut belum mengatur penyelenggaraan perlindungan anak dalam 5 bidang, yaitu; 1) hak sipil dan kebebasan, 2) hak lingkungan keluarga dan pengasuhan alternatif, 3) hak kesehatan dasar dan kesejahteraan, 4) hak atas pendidikan, pemanfaatan waktu luang dan kegiatan seni budaya, dan 5) hak perlindungan khusus, karena Peraturan Daerah tersebut masih menjadi satu dengan perlindungan perempuan dan belum membahas tersendiri tentang penyelenggaraan perlindungan anak.

Pengaturan secara khusus perlindungan anak sangat penting untuk dituangkan dalam regulasi atau peraturan daerah Kabupaten Kediri mengingat realitas empiris terkait anak sebagai berikut: 
1. Data Dispendukcapil menyebutkan, kepemilikan akta kelahiran berdasarkan kelompok umur 0019 tahun sebanyak 364.530 akta, sedangkan angka yang belum mempunyai akta lahir sebanyak 96.579 dari total penduduk kelompok umur tersebut sebesar 461.124 jiwa.

2. Data Polres menyebutkan angka korban kecelakaan lalu lintas yang melibatkan anak sangat tinggi sebanyak 308 kasus ditahun 2018 dan meningkat menjadi 389 kasus pada tahun 2019, hal ini terjadi karena anak-anak (di bawah umur 17 tahun) tidak dilaranga orang tua untuk mengendarai motor.

3. Menurut data Dinas Lingkungan Hidup ketersediaan taman bermain dan taman anak sangat kurang, hal ini terkait dengan Hak Tumbuh Kembang, anak yang memerlukan ruang untuk bermain, berolahraga, pendidikan yang sesuai dengan perkembangan fisik dan jiwanya.

4. Untuk memenuhi Hak partisipasi. Anak berhak mendapatkan akses, media dan sarana yang menunjang hak partisipasi, pun berhak atas informasi yang benar, menyampaikan pendapat baik melalui lisan, tulisan maupun ekspresi seni budaya. Anak perlu didengar pendapatnya tidak hanya dalam masalah domestik tetapi juga masalah-masalah publik.

5. Hak Partisipasi, sebagai ajang mengekspresikan dan menyampaikan keberatan pada keputusankeputusan yang mempengaruhi mereka. Hasil telaah kuesioner oleh informan terkait perlindungan anak di Kabupaten Kediri menunjukkan bahwa, indikator hak partisipasi dalam ruang publik yang dibutuhkan oleh anak yakni meliputi, ruang penghargaan atas penyampaian pendapat secara lisan maupun tulisan dan ekspresi seni, ruang kreasi publik masih belum tercukupi.

6. Dimensi permukiman berbasis indeks pembangunan desa adalah pembangunan Tempat Pembuangan Sampah yang ramah anak dan menjadi media belajar anak untuk peduli lingkungan sejak dini.

Dalam bagian ini menjelaskan indicator capaian yang telah dilakukan, sudah dilakukan dan yang belum dilakukan oleh Pemerintah Kabupaten Kediri dalam mewujudkan regulasi yang mengatur tentang hal tersebut. Indikator ini diidentifikasi dengan menggunakanin dikator yang dikeluarkan oleh Kementerian Pemberdayaan Perempuan dan Perlindungan Anak Republik Indonesia.

Berdasarkan indicator tersebut, maka identifikasi akan isu-isu anak yang ditemui di Kabupaten Kediri saat ini, serta bagaimana pemerintah Kabupaten Kediri merespon akan isu-isu tersebut melalui ketersediaan dan implementasi program ataupun peraturan, dan apasaja 


\section{Djoko Siswanto Muhartono}

Urgensi Regulasi Penyelenggaraan Perlindungan Anak di Kabupaten Kediri

program/fasilitasu mum yang mendukung ke arah terwujudnya regulasi tentang Penyelenggaraan Perlindungan Anak di Kabupaten Kediri.

Dari beberapa uraian di atas menunjukkan bahwa identifikasi tentang isu anak sangat bervariasi dan pemerintah Kabupaten Kediri telah berusaha untuk menyelesaikan permasalahan atas munculnya isu melalui berbagai tindakan seperti sosialisasi, pelatihan, penyediaan fasilitas meski ada yang belum terpenuhi, beserta menjalankan atau mengimplementasikan program dan kebijakan dalam pemenuhan untuk merespons tindakan terhadap isu anak yang muncul di lapangan.

Tindakan responsif menjadi sebuah kebutuhan yang harus dijalankan, apabila pemerintah Kabupaten Kediri dan jajarannya beserta masyarakat untuk memiliki tujuan mewujudkannya. Berdasarkan kebijakan yang dikeluarkan oleh Kementerian Pemberdayaan Perempuan dan Perlindungan Anak Republik Indonesia, terdapat beberapa tahap pengembangan Perlindungan anak. Kabupaten Kediri sangat membutuhkan regulasi tentang penyelenggaraan perlindungan anak.

Dalam terminology akademis, anak adalah termasuk anak yang mempunyai kebutuhan khusus dan anak terlantar harus diusahakan dalam perolehan hak dasarnya, karena mereka masih harus dibantu dalam memperoleh pemenuhan hak-haknya diantaranya hak kebahagiaan, hak kesehatan, hak pendidikan dan lainnya apalagi anak berkebutuhan khusus, mereka sering diartikan sebagai hilang atau terganggunya fungsi fisik atau kondisi abnormalitas fungsi struktur anatomi, psikologi, maupun fisiologi seseorang. Akibat dari kondisi seperti ini seseorang mengalami keterbatasan atau gangguan terhadap fungsisosialnya sehingga mempengaruhi keleluasan aktifitas fisik, kepercayaan dan harga diri yang bersangkutan, baik ketika berhubungan dengan orang lain maupun dengan lingkungan.

Selain memberikan perlindungan, pemerintah juga hadir menjamin mereka agar dapat berpartisipasi penuh dan setara dalam kehidupan bermasyarakat dan bernegara. Dengan adanya jaminan ini akan meminimalisir adanya tindakan diskriminatif dan terbuka kesempatan untuk berkembang dan berkreasi dalam konteks pembangunan Negara.

Pada kenyataannya, masih banyak dijumpai anak-anak terutama anak berkebutuhan khusus dan anak terlantar yang diabaikan. Mereka ini menyebar di segala tingkat usia, pendidikan, dan ekonomi, secara umum mereka lebih banyak menggantungkan hidupnya pada usaha meminta-minta (mengemis) dan tinggal secara berpindah-pindah, masih banyak anak yang belum terlindungi dari berbagai bentuk kekerasan dan eksploitasi dan tidak mendapatkan kesempatan memperoleh pendidikan minimal yang wajar apalagi yang memadai. Di sisi lain anak sebagai sosok yang rentan dan secara fisik dan mental masih tergantung pada orang dewasa, utamanya orangtua. Hal ini sangat 
mendukung terjadinya kasus kekerasan, eksploitasi maupun diskriminasi pada kelompok rentan ini yaitu anak.

Perkembangan yang terjadi di masa kini dimana kedua orangtua bekerja atau berkarier. Pada saat mereka pulang dengan harapan orangtua di rumah bisa beristirahat tetapi yang dijumpai adalah kerewelan, rengekan si kecil, maka yang terjadi adalah anak sebagai sasaran kemarahan orangtuanya. Hal ini tidak jarang terjadi di era globalisasi dan modernisasi ini yang di satu sisi membawa perkembangan teknologi informasi tetapi di sisi lain menimbulkan nilai-nilai baru yang dianggap modern. Peran serta orangtua, masyarakat dan pemerintah sangat dibutuhkan untuk merespon permasalahan tersebut secara komprehensif.

Kerawanan dan kerentanan anak untuk diperlakukan salah ini juga diakibatkan dari struktur sosial yang bersifat patriarkhi. Pola hubungan anak dan orangtua tidak egaliter melainkan ibarat bawahan dan atasan. Bawahan wajib menurut apa kata atasan dan atasan berwenang memutuskan apa yang terbaik bagi bawahan dalam kontrak kerja yang tidak imbang. Struktur demikian masih cukup kuat hadir di tengah keluarga dan masyarakat Indonesia, termasuk di Kabupaten Kediri. Anak dianggap warga kelas dua, anak dianggap sebagai calon manusia atau setengah manusia yang belum memiliki hak penuh, nasib anak masih tergantung pada orangtua, dan seterusnya. Undangundang dan Perda yang berkaitan dengan perlindungan anak yang bersifat memaksa akan memberikan pendidikan bagi orangtua dan masyarakat agar lebih ramah dan memberikan kasih sayang kepada anak.

Analisis situasi anak di Kabupaten Kediri seperti yang dipaparkan sebelumnya menjadi pertimabangan utama dalam menentukan skala prioritas upaya perlindungan kepada anak yang akan dicantumkan dalam peraturan daerah perlindungan anak Kabupaten Kediri yaitu:

(1) Hak terjaminnya program wajib belajar 12 tahun

(2) Hak atas kesehatan yang terbaik bagi semua anak

(3) Hak untuk bermain dan berekreasi serta memanfaatkan waktu luang

(4) Hak untuk memperoleh bantuan secara terpadu (media, psikososial, dan hukum) dalam pusat pelayanan terpadu bagi anak korban kekerasan;

(5) Hak yang sama tanpa diskriminasi dalam bidang pendidikan, sosial dan budaya bagi anak penyandang cacat;

(6) Perlindungan bagi anak terlantar/anak jalanan;

(7) Perlindungan kepada pekerja anak pada pekerjaan anak sektor informal

(8) Anak yang berhadapan dengan hukum;

(9) Anak yang tereksploitasi seksual; 


\section{Djoko Siswanto Muhartono}

Urgensi Regulasi Penyelenggaraan Perlindungan Anak di Kabupaten Kediri

(10) Anak korban penyalahgunaan narkotika, alkohol, psikotropika dan zat adiktif lainnya;

(11) Anak korban penularan HIV/AIDS;

(12) Anak korban bencana alam atau bencana sosial;

(13) Penyelenggaraan hak partisipasi anak (forum anak);

(14) Kelembagaan perlindungan anak (P2TP2A, Dinas Sosial;

(15) Forum anak; dan

(16) Perlindungan Anak dari penggunaan alat-alat teknologi.

Pemerintah Daerah diwajibkan menjamin terselenggaranya program wajib belajar minimal 12 (dua belas) tahun untuk semua anak. Penyelenggaraan program wajib belajar didukung oleh peran serta masyarakat. Oleh karenaituKeluarga dan orang tuawajibmemberikankesempatanseluasluasnyakepadaanakuntukmemperolehpendidikan. Penyelenggaraan Program wajib belajar minimal 12 (dua belas) tahun sebaiknya diatur dalam Peraturan Daerah tersendiri.

Setiap penyelenggara pendidikan dilarang mengeluarkan anak dari lembaga pendidikan tanpa adanya jaminan terhadap keberlangsungan pendidikan anak. Anak yang menyandang cacat fisik dan/atau mental wajib diberikan kesempatan yang sama dan aksesibilitas untuk memperoleh pendidikan biasa dan pendidikan luar biasa, demikian juga dengan anak yang berhadapan dengan hukum, anak yang mengalami kehamilan di luar pernikahan dan anak korban penularan HIV dan AIDS harus dilindungi hak-haknya guna memperoleh pendidikan.

Bagi anak usia 7 - 18 (tujuh sampai dengan delapan belas) tahun yang belum menyelesaikan pendidikan formalnya, dapat menempuh pendidikan melalui satuan pendidikan nonformal antara lain: Kelompok Belajar Paket A setara Sekolah Dasar (SD)/ Madrasah Ibtidaiyah (MI); Paket B setara Sekolah Menengah Pertama (SMP)/Madrasah Tsanawiyah (MTs); dan Paket C setara Sekolah Menengah Atas (SMA)/Madrasah Aliyah (MA), yang pada tahun 2019 berjumlah 68.

Solusi untuk meningkatkan kualitas pendidikan dapat dilakukan oleh pemkot dengan dibantu masyarakat setempat. Untuk efisiensi bidang anggaran pendidikan dapat difokuskan dengan mendayagunakan sarana SD untuk melanjutkan program pendidikan 12 tahun. Telah dijelaskan, bahwa Hak tercukupinya dan mendapat pendidikan menjadi salah satu variabel dasar bagi masyarakat dan kewajiban bagi pemerintah untuk memberikan hak pada anak untuk memberikan pendidikan secara gratis. Terbukti dari beberapa program Wajib Belajar 12 Tahun, dimana melalui program tersebut hak mengenyam bangku pendidikan anak, sudah dijamin oleh pemerintah negara. 
Namun, tidak hanya bisa mengandalkan pemberian program saja, pemerintah daerah pun juga harus turun untuk menjemput bola, memberikan stimulus, motivasi dan dorongan untuk meningkatkan niatan dan kemauan masyarakat untuk mengenyam bangku pendidikan. Memberikan sosialisasi terhadap pentingnya pendidikan dalam sebuah negara menjadi keharusan dan kewajiban bangsa seperti yang telah tertuang dalam baik Pembukaan UUD 1945 'Mencerdaskan Kehidupan Bangsa dan dapat dijelaskan pula bahwa Angka Partisipasi Sekolah (APS) Kabupaten Kediri pada tahun 2019, pada kelompok PAUD sebesar 119.36\% ,SD/MI 108.07\% dan SMP/MTs sebesar $100.92 \%$.

Adanya wadah atau instansi pembelajaran menjadi salah satu indikator yang menunjang tingkat pendidikan di suatu daerah. Di Kabupaten Kediri pada tahun 2019 jumlah PAUD tercatat sebanyak 987 buah, SD 914 dan SMP sebanyak 195 dan ditambah jumlah taman baca atau pojok literasi di satuan Pendidikan PAUD sebanyak 1.547 lokasi.

Sekolah yang memiliki berstatus negri dalam hal ini perlu ditingkatkan, karena hal tersebut sudah menjadi amanat dan tanggungjawab negara melalui pemerintahan. Bukan malah pendidikan di sektor swasta yang semakin berkembang. Akan menjadi ancaman dan bahaya jika sektor swasta akan mengalahkan sektor swasta. Pendidikan akan menjadi barang dagagangan dan jual beli layaknya komoditas, dan hanya masyarakat yang memiliki kapital yang dapat mengenyamnya.

Kondisi kesehatan anak di Kabupaten Kediri menurut catatan Dinas Kesehatan Kabupaten Kediri, jumlah ketercukupan gizi anak tahun 2019 sejumlah 85.221 jiwa dan jumlah mal nutrisi sebanyak 741 anak. Berangkat dari potret tersebut, maka diperlukan upaya meningkatkan kesadaran dan perilaku sehat masyarakat dalam langkah preventif oleh pemerintah seperti mengupayakan Undang-Undang Nomor 35 Tahun 2014 tentang Perlindungan Anak pasal 44 ayat 1 sampai 5 wajib diselenggarakan oleh Pemerintah Kabupaten Kediri.

Lahan tempat bermain diperlukan setiap anak sebagai sarana tumbuh kembang yang sehat. Dunia anak memang dunia bermain, dan bermain menjadi hak dan kebutuhan penting bagi anak. Tempat bermain bagi anak untuk berlatih peran, ekspresi diri, eksperimentasi sosial, dan pengembangan fisik dan psikis. Untuk itu pada setiap komunitas agar disediakan tempat bermain bagi anak yang menjamin keselamatan, kenyamanan dan kesehatan anak; memotivasi kreatifitas anak; dan mengandung unsur pendidikan.

Adanya anggaran untuk membuat sarana prasarana bermain, taman permainan ditingkat kecamatan sampai desa dan ketersediaan fasilitas umum seperti trotoar yang aman dan nyaman untuk anak, terutama anak berkebutuhan khusus sangat diperlukan dalam rangka menjamin terpenuhinya hak-hak anak. 


\section{Djoko Siswanto Muhartono}

Urgensi Regulasi Penyelenggaraan Perlindungan Anak di Kabupaten Kediri

Dewasa ini masyarakat yang menikmati perkembangan teknologi informasi juga mengalami pengaruh nilai-nilai baru yang dianggap modern. Kasus-kasus kekerasan semakin memposisikan anak sebagai korban karena kondisi anak yang lemah dan rentan. Kekerasan terhadap anak tidak hanya terjadi dalam lingkungan rumah tangga (domestik) saja, tetapi juga terjadi pada sektor publik, misalnya di lingkungan pendidikan. Tidak jarang ditemukan kasus anak yang mengalami masalah kekerasan fisik, psikis, seksual dan sosial. misalnya anak korban penganiayaan, penelantaran, pengusiran dan perlakuan salah (abuse) oleh orangtua atau orang lain. Bagi anak yang mengalami masalah tersebut pemerintah harus menyediakan children crisis center. Children crisis center merupakan tempat yang aman, dan bersifat child friendly (bersahabat bagi anak). Children crisis center tersebut dilengkapi dengan pendamping dari unsure pendidik, dokter, psikolog, ulama/rohaniwan dan berjaringan dengan pengacara anak serta Unit Renata di kepolisian. Sudah jelas urgensi pembentukan Lembaga ini sangat penting untuk segera dibentuk di Kabupaten Kediri.

Pemkab Kediri mendirikan Pusat Pelayanan Terpadu Pemberdayaan Perempuan dan Anak (P2TP2A) dengan Nomor: 188.45/516/418.08/2018 yang memberikan layanan berupa:

a. penyediaan rumah aman dan rumah singgah;

b. pembentukan Pusat Pelayanan Terpadu Anak;

c. pendirian dan pengelolaan panti asuhan anak;

d. pendirian tempat rehabilitasi anak korban penyalahgunaan narkotika, alkohol, psikotropika dan zat adiktif lainnya (napza);

e. pemberian bantuan hukum terhadap anak yang berhadapan dengan hukum;

f. bentuk-bentuk peran serta masyarakat lainnya yang berkaitan dengan penyelenggaraan perlindungan anak.

Nasib anak-anak penyandang cacat harus diperhatikan pemerintah. Karena mereka memiliki hak yang sama dengan anak normal. Bahkan tidak sedikit anak penyandang cacat memiliki bakat dan kemampuan yang lebih dibanding anak normal. Misalnya dalam seni lukis, seni musik dan seni yang lain. Jika diberikan kesempatan yang sesuai kemampuannya mereka akan menunjukkan kemampuan dan prestasinya. Anak cacat tidak butuh dikasihani, tetapi mereka memerlukan adanya pengakuan dan perlindungan hak sebagai sesama anak bangsa.Masih banyak sarana yang belum dinikmati anak-anak penyandang cacat sebagai sesama warga bangsa dan warga negara. Diskriminasi dalam pendidikan dan pekerjaan sangat mereka rasakan. Untuk itu ke depan pemerintah Kabupaten Kediri harus lebih bersikap adil dan peduli terhadap anak cacat. 
Beberapa perlindungan hak anak cacat meliputi: perlakuan sama (non diskriminasi) dalam pendidikan dan pengembangan diri anak; perlakuan sama (non diskriminasi) dalam kebebasan beribadah sesuai dengan agamanya; penyediaan sarana bagi anak tuna daksa (cacat fisik) di kantorkantor pemerintah dan tempat umum; sosialisasi kepada masyarakat luas mengenai bahasa isyarat yang penting bagi anak tuna rungu dan tuna wicara.

Anak-anak yang terlantar dan berkeliaran di jalanan harus memperoleh perlindungan hak mereka. Mereka harus diperhatikan hak pendidikan, kesehatan, latihan keterampilan, bimbingan sosial, mental dan spiritual demi menyongsong hari depan mereka. Pengaruh negatif di jalan dari tindakan kriminal perlu dihentikan. Untuk itu pemerintah telah bekerjasama dengan LSM dalam membina kegiatan di rumah singgah, namun usaha tersebut banyak yang mengatakan masih gagal. Untuk melakukan gerakan sayang anak jalanan tidak cukup dengan menghimbau masyarakat untuk tidak memberi sedekah kepada anjal yang mengamen atau mengemis di jalanan. Perlu gerakan masyarakat peduli mengenai kesulitan membina anak jalanan dari upaya menghilangkan stigma yang disandang baik sebagai pelaku atau penyandang pembuat resah masyarakat. Kehidupan jalanan tidak ada harapan masa depan. Pemerintah akan memberikan perlindungan hak kepada anak-anak terlantar ini dan memberikan sanksi tegas kepada pihak-pihak yang melakukan eksploitasi.

Akibat kemiskinan dan ketidakkemampuan ekonomi keluarga akibatnya banyak anak yang membantu ekonomi keluarga. Rendahnya tingkat pendidikan yang dicapai menjadikan anak terpaksa bekerja pada sektor informal seperti Pekerja Rumah Tangga Anak, Penyemir Sepatu Anak, Pedagang Asongan Anak, Pengamen Anak, Pemulung Anak, Tukang Parkir anak, pekerjaan Sektor Informal lainnya yang mempekerjakan anak. Anak yang bekerja di sektor informal akan kehilangan kesempatan melanjutkan pendidikan, selain itu juga kehilangan kesempatan untuk pengembangan dirinya. Faktor-faktor keberatan pada anak yang bekerja seperti ini dinyatakan dalam konvensi International Labour Organization (ILO) adalah kemungkinan anak yang bekerja mengalami ancaman pada kesehatnnya, pendidikan, dan ancaman eksploitasi dan perlakuan salah lebih lanjut.

Anak yang berkonflik dengan hukum adalah anak yang terlibat dalam sisitem hukum karena disangka atau didakwa melakukan tindak kriminal. Apa yang dimaksud yang berhadapan dengan hukum atau berkonflik dengan hukum umumnya melakukan tindakan yang meskipun melawan huklum tapi masih dikategorikan pelanggaran ringan atau dapat juga dikatakan sebagai kenakalan remaja yang melawan hukum / juvenile.

Fakta di lapangan menunjukan seringkali anak yang berkonflik dengan hukum diperlakukan sama dengan orang dewasa yang melakukan tindakan melawan hukum atau kriminal. Perwakilan 


\section{Djoko Siswanto Muhartono}

Urgensi Regulasi Penyelenggaraan Perlindungan Anak di Kabupaten Kediri

kepada anak yang berkonflik dengan hukum disamkan dengan pelaku kriminal umumnya dari proses penegakan hukum seperti penagkapan, penyididkan, persidangan, dan akhirnya tindakan hukum. Penyamaan perlakuan akan membuka kemungkinan anak mengalami kekerasan, ekspliotasi, dan kekejaman selama proses hukum. Sehingga anak mengalami kecemasan, trauma, dan ketakutan berlebihan setelah mengalami proses hukum.

Di Kabupaten Kediri, berdasarkan data Badan Narkotika Nasional (BNN) 2019 pengguna narkoba yang melapor berdasarkan sattus pasien sebanyak 12 anak semuanya laki-laki. Semuanya berstatus pulih dan dikembalikan ke orang tua setelah melalui tahapan rehabilitasi dan konseling.

Anak yang terjangkit HIV/AIDS tidak hanya terancam kondisi kesehatan fisik dan kelansungan hidupnya, namun juga mengalami penderitaan akibat kehilangan perlindungan dan kasih sayang dari keluarga dan lingkungan terdekat. Ancaman penderitaan bagi anak penderita HIV/AIDS bersumber dari stigma, deskriminasi, sikap mengeksklusi dan mengisolasi anak dari lingkungannya yang kemungkinan besar akan mengganggu proses pendidikan anak.

Penderitaan tersebut di atas kemungkinan akan menimbulkan dampak psikososial pada anak seperti rendah diri, stress dan munculnya gangguan - gangguan emosional perilaku yang lain.Hal tersebut diatas menjadi dasar pemikiran bagi upaya untuk memberikan perlindungan kepada anak dengan mendorong pemerintah memberikan komitmen dan dukungan dalam bentuk penyadaran, penyediaan fasilitas dan layanan yang menjamin kesejahteraan dan kehidupan sosial anak dengan HIV/AIDS

Upaya melindungi anak dari korban bencana meliputi jaminan atas kebutuhan fisik dasar, kesehatan dan pendidikan. Kabupaten Kediri juga mempunyai potensi bencana alam yang berasal dari letusan maupun erupsi Gunung Kelud yang berada di wilayah Kabupaten Malang, Blitar dan Kediri. Perlakuan perlindungan dan pemeliharaan terhadap anak pasti akan berbeda pula.

Hak partisipasi tersebut, tidak dapat dipungkiri seringkali diabaikan dan dianggap tidak ada. Oleh karena itu Pemerintah Kabupaten Kediri diharapkan dapat menjamin dan memfasilitasi partisipasi anak ini dengan memfasilitasi terbentuk dan terselenggaranya forum anak yang melibatkan anak, unsur pemerintah kota, lembaga swadaya masyarakat dan tokoh masyarakat melalui Keputusan Bupati Kediri tentang Pembentukan Forum Anak Kabupaten Kediri Periode 2018-2020 Nomor: 188.45/515/418.08/2018.

Agar kebijakan Perlindungan Anak di Kabupaten Kediri efektif dalam pelaksanaannya dibutuhkan adanya Gugus Tugas yang dibentuk oleh Kepala Daerah yang mempunyai tugas pokok: mengkoordinasikan pelaksanaan kebijakan dan pengembangannya, menetapkan tugas-tugas dari 
anggota Gugus Tugas, melakukan sosialisasi, advokasi dan komunikasi informasi dan edukasi kebijakan PPA, mengumpulkan dan deseminasi data dasar, melakukan analisis kebutuhan yang bersumber dari data dasar, menentukan fokus dan prioritas program dalam mewujudkan perda PPA yang disesuaikan dengan potensi daerah, menyusun dan mekanisme kerja, melakukan monitoring, evaluasi dan pelaporan.

\section{KESIMPULAN}

a. Pada hakekatnya anak memiliki hak yang sama dengan warga negara lain, terutama dalam bidang layanan dasar seperti administrasi kependudukan, pendidikan, kesehatan dan bersosialisasi, sebagai penerus generasi masa depan, hak layanan dasar wajib diberikan kepada setiap anak. Posisi strategi sini menuntun setiap anak mampu tumbuh dan berkembang secara optimal, berkualitas, dan terkendali. Pemerintah dan masyarakat berkewajiban membantu dan memastikan agar setiap anak dapat memperoleh pelayanan dasar secara berkualitas dan memadai.

b. Secara faktual menunjukkan bahwa tidak semua anak memiliki situasi dan kesempatan yang sama. Masih terdapat anak yang memiliki keterbatasan secara fisik, mental, sosial, dan sensorik lainnya. Anak-anak dengan kondisi ini disebut dengan anak berkebutuhan khusus. Kondisi kurang lebih sama juga dihadapi oleh anak-anak yang secara social tidak terintegrasi dalam keluarga asli akibat ketidakhadiran keluarga. Anak seperti ini sering disebut dengan anak terlantar. Karena keterbatasan ini maka mereka mengalami hambatan-hambatan dalam mengakses layanan dasar yang disediakan. Oleh karena itu,diperlukan instrument atau dukungan lain baik secara material maupun kebijakan agar keterbatasan-keterbatasan yang ada tidak menjadi halangan dalam mengakses dan memenuhi kebutuhan akan hak-hak dasar yang layak dan memadai.

c. Atas pertimbangan ini maka secara material, seluruh layanan kebutuhan dasar anak harus mempertimbangkan aksesabilitas kemudahan bagi anak-anak juga anak yang mempunyai kebutuhan khusus dan terlantar. Selain secara material, secara social berada pada ruang umum yang memungkinkan menjadi obyek perilaku-perilaku tertentu. Secara umum tidak semua masyarakat dapat menerima keberadaan anak berkebutuhan khusus dan terlantar secara penuh. Beberapa masih memandang anak-anak tersebut sebagai anak cacat, menyimpang, atau bahkan kutukan dari Tuhan. Stigma negatif ini sangat berpengaruh terhadap proses tumbuh kembang mereka. Misalnya seringkali anak penyandang disabilitas menjadi sasaran tindakan diskriminatif dan kekerasan. 


\section{Djoko Siswanto Muhartono}

Urgensi Regulasi Penyelenggaraan Perlindungan Anak di Kabupaten Kediri

d. Bentuk dari perlindungan ini adalah adanya kebijakan yang mengafirmasi pemenuhan hakhak mereka. Selain itu juga pemenuhan-pemenuhan kebutuhan material dalam bidang layanan dasar yang melingkupi administrasi kependudukan, pendidikan, Kesehatan dan sosialisasi. Pada praktiknya pemberlakuan peraturan tentang Perlindungan anak berguna untuk peningkatan kesejahteraan dan perlindungan anak, serta terpenuhinya hak-hak anak seperti yang diamanatkan oleh UUD 1945 dan Konvensi Hak Anak Internasional. Disisi lain, peraturan daerah ini akan menjadi dasar hukum bagi penyediaan fasilitas dan pelayanan yang terbaik bagi anak, khususnya di Kabupaten Kediri, yang akan dilakukan oleh pemerintah dan masyarakat, dimana masyarakat yang dimaksud adalah orang tua, perguruan tinggi, Lembaga Swadaya Masyarakat (LSM) dan kalangan usaha.

\section{DAFTAR PUSTAKA}

Imam Sudiyat, 1982, Asas Hukum Adat, BekalPengantar, Yogjakarta: Liberty.

Jimly, Asshiddiqie, 2008, Menuju Negara Hukum Yang Demokratis, Jakarta: SekretariatJenderal dan KepaniteraanMahkamahKonstiusi.

Jones, N. 2009, Child protection and social protection systems in West and Central Africa. UNICEF WCARO commissioned report.

Kabupaten Kediri dalam Angka 2018.

Kementerian Hukum dan HakAsasiManusiaRepublik Indonesia, 2017, JaringanDokumentasi dan Informasi Hukum Nasional (JDIHN), Jakarta.

KPPA. 2016, Perlindungan Anak: BahanAdvokasiKebijakan PA. Jakarta: Kementerian Pemberdayaan Perempuan dan Perlindungan Anak Republik Indonesia.

Kuntowijoyo, 1990, Paruh Industrialisasi Indonesia Yang Manusiawi, Makalah Seminar di Pusat Antar Universitas (PAU) UGM, Yogjakarta.

Lili Rasjidi, 1985, Filsafat Hukum: Apakah Hukum Itu, Bandung: RemadjaKarya.

LKPJ Kabupaten Kediri tahun 2018.

Malone, 2013, Child Friendly Cities Initiative and Sustainable Development: addressing rapid urbanization and children's rights through local and global partnerships. Local Environtmental Journal.

Naskah Akademik Rancangan Peraturan Daerah Kabupaten Cilacap Tentang Perlindungan Anak Penyandang Disabilitas dan Anak Terlantar, 2017. 
PUBLICIANA : JURNAL ILMU SOSIAL DAN ILMU POLITIK

VOLUME 14 NO 1

ISSN : 1979 - 0295 | E-ISSN : $2502-7336$

Satya Arinanto, 2008, Hak Asasi Manusia dan Transisi Politik di Indonesia, Jakarta: Pusat Studi Hukum Tata Negara FHUI.

UNICEF Indonesia. 2014 Acuan Anggaran Publik Untuk Perlindungan Anak: Ringkasan Eksekutif Studi Uji Coba di Indonesia. Jakarta: Unicef Indonesia. 